\title{
Pore system changes of damaged Brazilian oxisols and nitosols induced by wet-dry cycles as seen in 2-D micromorphologic image analysis
}

\author{
LUIZ F. PIRES ${ }^{1,2}$, KLAUS REICHARdT ${ }^{2}$, MIGUEL COOPER ${ }^{3}$, FABIO A.M. CÁSSARO ${ }^{1}$, \\ NIVEA M.P. DIAS ${ }^{4}$ and OSNY O.S. BACCHI ${ }^{2}$ \\ ${ }^{1}$ Laboratório de Física Aplicada a Solos e Ciências Ambientais, Departamento de Física \\ Universidade Estadual de Ponta Grossa, UEPG, Av. General Carlos Cavalcanti, 4.748 \\ Campus de Uvaranas, 84030-900 Ponta Grossa, PR, Brasil \\ ${ }^{2}$ Laboratório de Física dos Solos, Centro de Energia Nuclear na Agricultura, USP/CENA, Av. Centenário, 303 \\ Caixa Postal 96, 13400-970 Piracicaba, SP, Brasil \\ ${ }^{3}$ Departamento de Solos e Nutrição de Plantas, Escola Superior de Agricultura Luiz de Queiroz, USP/ESALQ \\ Av. Pádua Dias, 11, Caixa Postal 9, 13418-900 Piracicaba, SP, Brasil \\ ${ }^{4}$ Departamento de Ciência do Solo, Universidade Estadual de Ponta Grossa, UEPG, Av. General Carlos Cavalcanti, 4.748 \\ Campus de Uvaranas, 84030-900 Ponta Grossa, PR, Brasil \\ Manuscript received on January 13, 2008; accepted for publication on September 9, 2008; \\ contributed by KLAUS REICHARDT*
}

\begin{abstract}
Soil pore structure characterization using 2-D image analysis constitutes a simple method to obtain essential information related to soil porosity and pore size distribution (PSD). Such information is important to infer on soil quality, which is related to soil structure and transport processes inside the soil. Most of the time soils are submitted to wetting and drying cycles (W-D), which can cause important changes in soils with damaged structures. This report uses 2-D image analysis to evaluate possible modifications induced by W-D cycles on the structure of damaged soil samples. Samples of three tropical soils (Geric Ferralsol, GF; Eutric Nitosol, EN; and Rhodic Ferralsol, RF) were submitted to three treatments: $0 \mathrm{WD}$, the control treatment in which samples were not submitted to any W-D cycle; 3WD and 9WD with samples submitted to 3 and 9 consecutive W-D cycles, respectively. It was observed that W-D cycles produced significant changes in large irregular pores of the GF and RF soils, and in rounded pores of the EN soil. Nevertheless, important changes in smaller pores $(35,75$, and $150 \mu \mathrm{m})$ were also observed for all soils. As an overall consideration, it can be said that the use of image analysis helped to explain important changes in soil pore systems (shape, number, and size distribution) as consequence of W-D cycles.
\end{abstract}

Key words: soil bulk density, soil water content, soil porosity, micromorphology, soil structure, compaction.

\section{INTRODUCTION}

The soil pore system (SPS) is directly related to the shape, size and spatial arrangement of individual soil particles and aggregates. This arrangement of soil constituents originates different soil pore distributions and porosities, which is crucial, for instance, for good soil aeration, water infiltration, and root penetration (Pagliai

\footnotetext{
* Member Academia Brasileira de Ciências

Correspondence to: Luiz Fernando Pires

E-mail: luizfpires@gmail.com
}

1987). Modifications on soil pore size distribution (PSD), pore shape, and pore arrangement can be used to characterize possible SPS changes due to W-D cycles (Hussein and Adey 1998).

Compaction is one of the most important causes of SPS changes (Pires et al. 2004). These SPS alterations can raise questions regarding the representativeness of soil hydraulic characterizations performed in the laboratory. Soil compaction can be a result of compression processes which can produce strong modifications in SPS. 
As a result, soil bulk density increases followed by soil pore volume decreases can in general be observed.

Wetting and drying (W-D) cycles can also act as a mechanism of SPS changes (Pagliai et al. 1987, Hussein and Adey 1998, Bresson and Moran 2003). During a WD cycle the soil pore system can be modified, mainly due to changes in soil particle orientations. Some authors have shown that sequences of W-D cycles can cause, for instance, aggregate formation in non-aggregated soils. It can in some circumstances regenerate structurally damaged soils and can induce, by increasing soil porosity, significant changes in SPS (Pagliai 1987, Sartori et al. 1985, Newman and Thomasson 1979, Telfair et al. 1957).

The 2-D image analysis of resin impregnated soil blocks has been used to evaluate SPS changes at meso and microscopic scales. It allows evaluating variations of the type and size distribution of pores in damaged soil samples after W-D cycles (Pillai and McGarry 1999). It can give useful information about the number, area, perimeter, diameter, shape, arrangement, and PSD.

The image analysis technique to quantify and characterize the porosity of impregnated soil blocks was firstly introduced by Jongerius et al. (1972) and Murphy et al. (1977a, b). Several other contributions describing its use were presented afterwards (Cooper et al. 2005, Horgan 1998, Thompson et al. 1992, Ringrose-Voase 1990, Bouma et al. 1979, Bullock and Thomasson 1979).

The objective of this study was to evaluate the ability of the 2-D micromorphologic image analysis in measuring the behavior of damaged SPS of weathered soils (Oxisols and Nitosols) with low clay activity from Brazil, through evaluations of PSD and pore shape changes, when these soils are submitted to sequences of W-D cycles.

\section{MATERIALS AND METHODS}

Soil core samples were collected from the surface layer of three soils characterized as Geric Ferralsol (GF), Eutric Nitosol (EN), and Rhodic Ferralsol (RF) (Table I) (FAO soil classification 1998). The experimental area is located in Piracicaba, SP, Brazil $\left(22^{\circ} 4^{\prime} \mathrm{S} ; 47^{\circ} 38^{\prime} \mathrm{W}\right.$; $580 \mathrm{~m}$ above sea level).

Twenty-seven samples, nine from each soil, were collected at the soil surface layer (3-7 cm depth) with aluminum cylinders $(h=3.0 \mathrm{~cm}, D=4.8 \mathrm{~cm}, V=$ $55 \mathrm{~cm}^{3}$ ). According to the classical sampling procedure, the cylinders were introduced into the soil by the weight of a rubber mass falling from a given height. The extracted cylinders were completely filled with the soil and the excessive soil was carefully trimmed off each volumetric ring so that the volume of the ring was completely filled with the soil and the top and bottom surfaces of the sample were flat assuring that the soil volume could be taken as the cylinder volume.

To impose W-D cycles on the collected samples the capillary rise method was chosen to saturate them (Klute 1986). Twenty-four hours was found to be the necessary time interval to saturate the samples and to avoid entrapped air bubbles inside them. After saturated the samples were dried by submitting them to a pressure of $400 \mathrm{kPa}$ in a pressure chamber (Klute 1986). These two steps consisted in a W-D cycle.

Three different treatments were investigated: 0WD, the control treatment, in which samples were not submitted to any W-D cycle; $3 \mathrm{WD}$, samples submitted to $3 \mathrm{~W}-\mathrm{D}$ cycles, and 9WD, samples submitted to $9 \mathrm{~W}-\mathrm{D}$ cycles.

For image analysis nine samples of each soil were used and for each treatment three samples were selected for impregnation with resin. From the impregnated samples two vertical slices $(4.6 \times 3.0 \mathrm{~cm})$ were cut (Murphy 1986) and a small area $\left(2.8 \times 1.1 \mathrm{~cm}^{2}\right)$, located next to the border of the samples, was selected for 2-D image analysis procedures (Fig. 1).

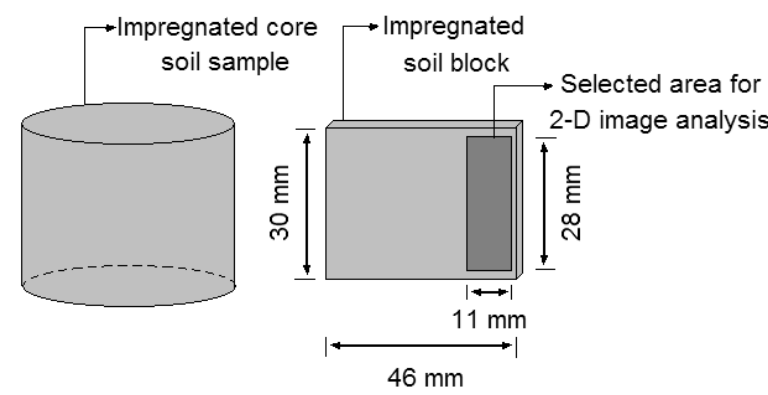

Fig. 1 - Schematic diagram of the soil block $\left(4.6 \times 3.0 \mathrm{~cm}^{2}\right)$ used for 2-D micromorphologic image analysis.

A color CCD camera of $1024 \times 768$ pixel resolution (area of $100 \mu \mathrm{m}^{2}$ pixel $^{-1}$ ) coupled to a petrographic microscope (10 times magnification) was used to obtain the digital images. The images were stored on a PC and processed by the Noesis-Visilog ${ }^{\circledR} 5.4$ computer software. 
TABLE I

Physical and chemical characteristics of the 0-0.10 $\mathrm{m}$ layer for the experimental soils.

\begin{tabular}{|c|c|c|c|}
\hline \multirow[b]{2}{*}{ Characteristic } & \multicolumn{3}{|c|}{ Soil } \\
\hline & $\begin{array}{c}\text { Geric Ferralsol } \\
\text { (GF) }\end{array}$ & $\begin{array}{c}\text { Eutric Nitosol } \\
(\mathrm{EN})\end{array}$ & $\begin{array}{c}\text { Rhodic Ferralsol } \\
\text { (RF) }\end{array}$ \\
\hline Sand $(\%)$ & 66 & 24 & 15 \\
\hline Clay $(\%)$ & 28 & 43 & 56 \\
\hline Silt $(\%)$ & 6 & 33 & 29 \\
\hline Dry Bulk density $\left(\mathrm{Mg} \cdot \mathrm{m}^{-3}\right)$ & 1.53 & 1.61 & 1.34 \\
\hline Particle density $\left(\mathrm{Mg} \cdot \mathrm{m}^{-3}\right)$ & 2.55 & 2.68 & 2.54 \\
\hline Organic matter $\left(\mathrm{g} \cdot \mathrm{dm}^{-3}\right)$ & 16.0 & 20.2 & 27.0 \\
\hline $\mathrm{pH}\left(\right.$ in $\left.\mathrm{CaCl}_{2}\right)$ & 3.9 & 5.3 & 4.9 \\
\hline $\mathrm{Ca}\left(\mathrm{mmol}_{\mathrm{c}} \cdot \mathrm{kg}^{-1}\right)$ & 13.0 & 29.0 & 27.0 \\
\hline $\mathrm{K}\left(\mathrm{mmol}_{\mathrm{c}} \cdot \mathrm{kg}^{-1}\right)$ & 2.6 & 4.3 & 3.4 \\
\hline $\mathrm{Mg}\left(\mathrm{mmol}_{\mathrm{c}} \cdot \mathrm{kg}^{-1}\right)$ & 4.0 & 20.0 & 15.0 \\
\hline
\end{tabular}

Pore area $(\phi)$ of the selected soil samples was evaluated dividing the total void space area of the selected cross-section by the total area of the field under analysis, expressed as a percentage. Measured values of $\phi$ in general underestimate the volumetric total porosity. During the analysis pores were separated according to their shape and size. Soil pores were divided into three shape classes (rounded, elongated, and irregular) characterized using two indexes and thresholds (Lima et al. 2006, Cooper et al. 2005). Pores of each shape group were subdivided into three different size classes (20-50; 50-500; and $>500 \mu \mathrm{m}$ ).

The SAS software (SAS Institute 1996) was used for data processing. Normality tests were performed on the data prior to their statistical processing. An analysis of variance (ANOVA) and the Duncan test $(\alpha=0.05)$ were performed to analyze statistical differences and to discriminate means.

\section{RESULTS AND DISCUSSION}

Pore shape presented important changes due to W-D cycles and they induced changes in SPS (Figs. 2A to 2C). For the GF soil (Fig. 2A), the W-D cycles promoted a decrease in the number of rounded pores, a slight increase in the elongated ones, and a significant increase in the irregular pores. For the control samples (0WD), the $\phi$ composition was: rounded pores $60 \%$, irregular pores
$31 \%$, and elongated ones $9 \%$, indicating that the $3 \mathrm{WD}$ and 9WD treatments, showed remarkable differences in relation to $0 \mathrm{WD}$. Nevertheless, $3 \mathrm{WD}$ and $9 \mathrm{WD}$ did not presented substantial differences regarding to their pore shape. As an example of the mentioned changes, irregular pores, that were initially responsible for $31 \%$ of $\phi$ for $0 \mathrm{WD}$, after $9 \mathrm{~W}$-D cycles represented $62 \%$ of $\phi$.

For the EN soil (Fig. 2B), with exception to irregular pores, the $3 \mathrm{WD}$ presented the most significant modifications, mainly in the rounded pores. A possible explanation for this result can be the small number of replicates for $3 \mathrm{WD}$ (only 2 replicates) as compared to the other treatments (6 replicates). This small number of replicates for the $3 \mathrm{WD}$ treatment was due to problems during soil impregnation with resin. Comparing 0WD samples to those submitted to $9 \mathrm{~W}-\mathrm{D}$ cycles, the increase factor for rounded, elongated, and irregular pores was $2.2,3.2$, and 3.6, respectively. Although representing only $15 \%$ of $\phi$ after $9 \mathrm{~W}$-D cycles, the high increase factor observed for elongated pores (3.2) shows that W-D cycles improved the EN soil from the agronomic point of view, as also observed by Sartori et al. (1985).

The RF soil showed similar results as those found for the GF soil (Fig. 2C). A slight decrease of rounded pores after $9 \mathrm{~W}-\mathrm{D}$ cycles was observed. Initially rounded pores represented $42 \%$ of $\phi(0 \mathrm{WD})$, a percentage that decreased to $24 \%$ after $9 \mathrm{~W}-\mathrm{D}$ cycles. In relation to elongated pores there were minimum differences among 


\section{Geric Ferralsol (GF)}

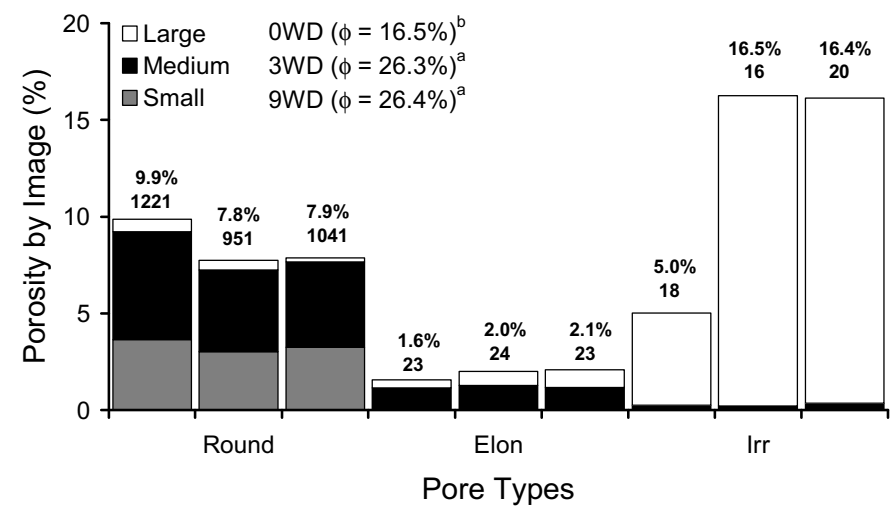

(A)

Eutric Nitosol (EN)

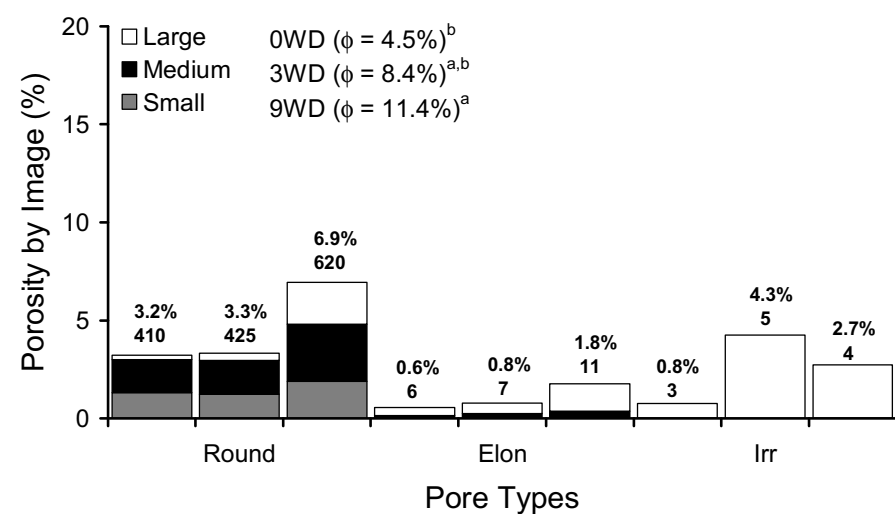

(B)

Rhodic Ferralsol (RF)

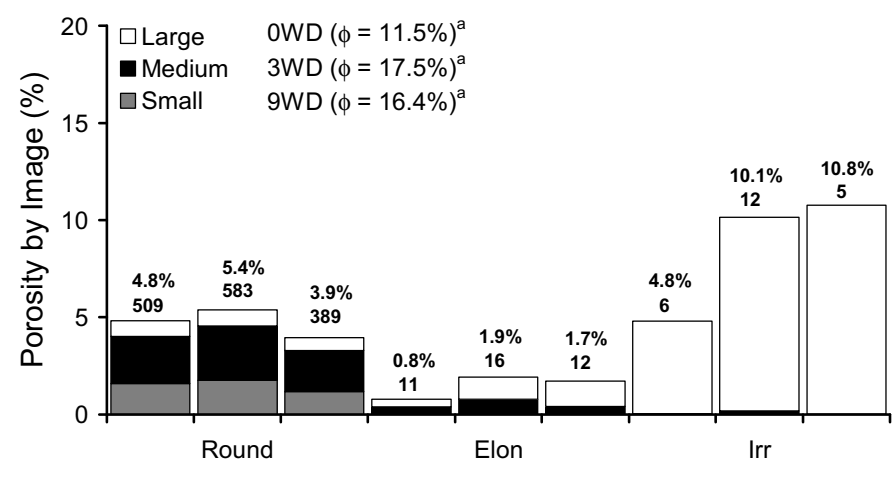

Pore Types

(C)

Fig. 2 - Effects of wetting and drying (W-D) cycles on the pore shape of damaged samples for the three soils. Round = rounded; Elon = elongated; Irr $=$ irregular; $\phi=$ total porosity by image; TNP = total number of pores; $0 \mathrm{WD}$ (samples not submitted to W-D cycles), 3WD (samples submitted to 3 W-D cycles), and 9WD (samples submitted to 9 W-D cycles) treatments; Porosity values followed by the same letters are not significantly different according to the Duncan test $(\alpha=0.05)$. 
treatments. The percentage in $\phi$ due to irregular pores changed from $42 \%$ to $66 \%$ after $9 \mathrm{~W}$-D cycles. For the $\mathrm{RF}$ soil, both rounded and irregular pores are the main pores present in the impregnated analyzed blocks for 0WD. Nevertheless, it was observed that the number of the irregular pores increased enormously after the sequences of $\mathrm{W}-\mathrm{D}$ cycles for this soil.

The results for the GF and RF soils show that few sequences of W-D cycles can cause strong modifications on SPS of damaged (compacted) samples. On the other hand, W-D cycles did not promote any great change in any particular class of pore of EN samples. A constant increase in $\phi$ due to the W-D cycles was only observed for this soil. Pillai-McGarry and Collis George (1990) working with puddled and non-puddled soils found that a minimum of $3 \mathrm{~W}$-D cycles caused significant changes in soil structure; however, in another study, Pillai-McGarry (1991) showed that more than 3 W-D cycles were needed to regenerate the original structure of the topsoil layer of a Vertisol. Rajaram and Erbach (1999) indicated that only one cycle of W-D changed several properties (cone penetration resistance, soil cohesion, aggregate size) of a clay loam soil. The results presented by these authors indicated that there is no detailed information about the number of cycles needed to cause any significant change in SPS.

Pillai-McGarry (1991) investigating Vertisols suggested that W-D cycles represent an important process in soil structuring. Sarmah et al. (1996) found an increase in water infiltration and a reduction in shear strength due to low to moderate changes in soil structure of samples after repeated W-D cycles. Pardini et al. (1996) also indicated possible variations of surface roughness, porosity, and pore size distribution during W-D cycles. They found after three W-D cycles an increase in soil porosity induced by the formation of big cracks and fissures. The presence of cracks was not observed in our soil samples, although W-D cycles could promote the formation of microfissures. However, our studied soils are not composed by swelling clays that present large content of smectite clay minerals (Hussein and Adey 1998). Generally this kind of behavior occurs in some clayey soils in which it is common to observe soil cracks or fissures (Chertkov and Ravina 2000).

Despite numerous studies about the effect of W-
D cycles in soil structure of swelling soils like Vertisols, there are only a few reports about the influence of these cycles on the structure of tropical not swelling soils. Viana et al. (2004) conducted an experiment to investigate the structural modifications engendered by W-D cycles in Brazilian Latosols (Oxisols) with different mineralogical properties. They observed that after W-D cycles important alterations occurred in both soil shape and structural pattern, which were attributed to a re-organization of soil particles during the plasma shrinkage after drying process. Oliveira et al. (2005) also reported the influence of W-D cycles on the structure of Brazilian Latosols and they reported that there is a close interdependence among mineralogical composition, aggregate stability, and water-dispersible clay influenced by the cycles.

Soils of reduced aggregate stability with kaolinitic mineralogy are more susceptible to the action of W-D on the water-dispersible clay. Soil mineralogy has a substantial effect on aggregate stability and dispersion, being the smectitic soils the most dispersive and kaolinitic ones the least. The dispersivity of illitic soils is intermediate, but may sometimes exceed that of smectitic soils. In soils dominated by 2:1 clays (Vertisols), the aggregate stability is affected mainly by polyvalent metal-organic matter complexes that form bridges between the negatively charged clay platelets. In 1:1 claydominated soils, the stability is attributed to the binding capacity of the minerals themselves (Wakindiki and Ben-Hur 2002). Unfortunately as we did not carry out mineralogical composition analysis in our work it is impossible to compare our results with those obtained by Viana et al. (2004) and Oliveira et al. (2005) for the GF soil and the RF soil (both Latosols). In the world it is also possible to find some scientific literature about the effect of W-D cycles on the structure of not swelling soils in which the authors describe that important changes in SPS occurs after sequences of soil hydration and dehydration (Augeard et al. 2008, Bresson and Moran 2004, Li et al. 2004, Attou and Bruand 1998, Bresson and Moran 1995).

In relation to TNP for the GF soil (Fig. 2A) there were just slight differences among treatments in relation to changes in the elongated and irregular pores. This means that the increase in $\phi$ among treatments occurred 
due to an increase in the area of soil macropores (Pires et al. 2005). For the 3WD treatment, only the few irregular large pores contributed substantially to the observed changes in $\phi$. W-D cycles caused changes in TNP mainly due to decreases in the number of small pores $(35,75$, and $150 \mu \mathrm{m}$ ) (Fig. 3A). However, TNP was not substantially modified in relation to large pores (from 250 to $1000 \mu \mathrm{m}$ ) This confirms that the observed increase in $\phi$ among treatments probably occurred due to an increase in the area of soil macropores. Pardini et al. (1996) also reported increases in soil porosity of clayey soils due to the raising of the number of pores and also to the formation of cracks and fissures in the structure. The reduction of the contribution of rounded pores to $\phi$ can be explained by the reduction of TNP among treatments.

For the EN soil (Fig. 2B), the W-D cycles raised the number of rounded and elongated pores. This caused a constant growth in TNP and also increased the contribution of these pores to $\phi$ among treatments. In relation to small pores $(35,75$, and $150 \mu \mathrm{m})$ the EN soil presented an opposite behavior in relation to those noticed for the GF soil (Fig. 3B). Nevertheless, the application of W-D cycles did not result in substantial differences related to larger pores (250 to $1000 \mu \mathrm{m})$. The constant mentioned increase in TNP for different treatments is confirmed by analyzing the areas below the curve $\left(\mathrm{A}_{\mathrm{BC}}\right)$ of the plot shown in Figure 3B.

For the RF soil (Fig. 2C), a decrease in the total number of rounded pores was observed between $0 \mathrm{WD}$ and 9WD treatments and also the maintenance of the number of elongated and irregular pores (except for 3 WD). Probably the observed changes in $\phi$ were due to the increase of the area of large macropores for 9WD (Pires et al. 2005). Figure 3C shows that this soil presented an increase in TNP for smaller pores $(35,75$, and $150 \mu \mathrm{m}$ ) for 3WD and a decrease for 9WD in relation to 0WD. As compared to the other soils, the TNP of large pores (from 250 to $1000 \mu \mathrm{m}$ ) for this soil was not substantially affected by the W-D cycles. This confirms that the changes in $\phi$ are related to the increase of the area of this type of pores after the application of W-D cycles. The W-D cycles produced important changes in PSD for the GF soil samples (Fig. 4A). There was a great variation in TNP of irregular pores larger than $500 \mu \mathrm{m}$ and rounded pores with radii between 50 and $500 \mu \mathrm{m}$.

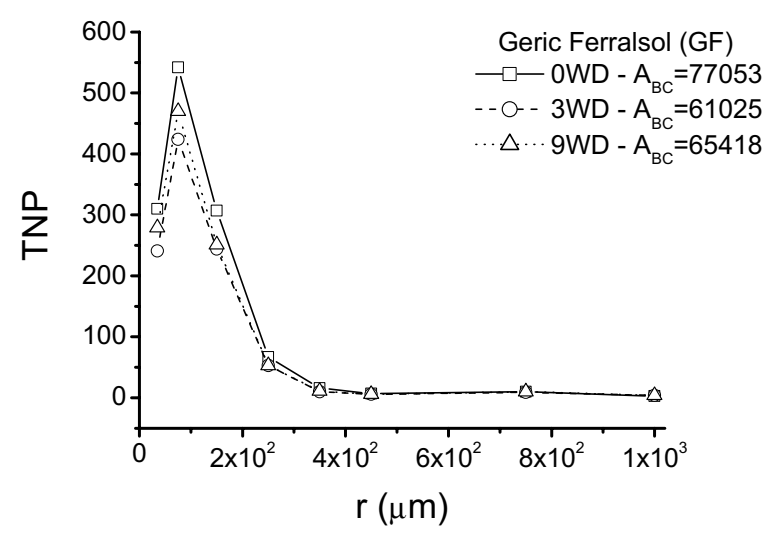

(A)

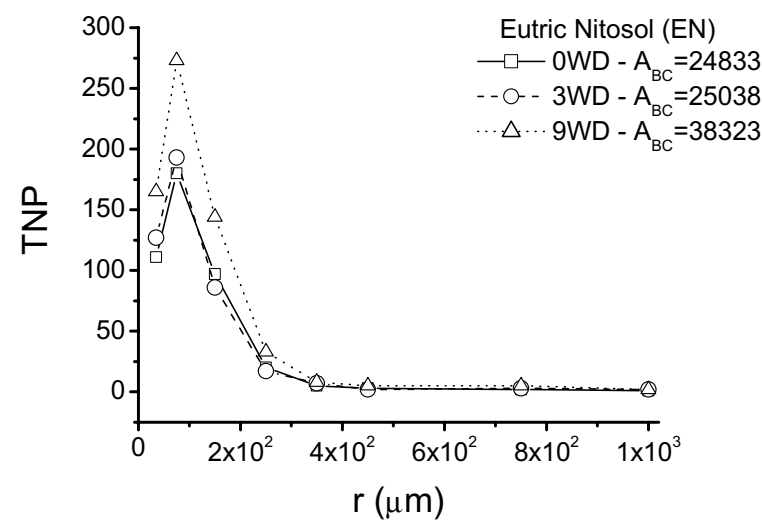

(B)

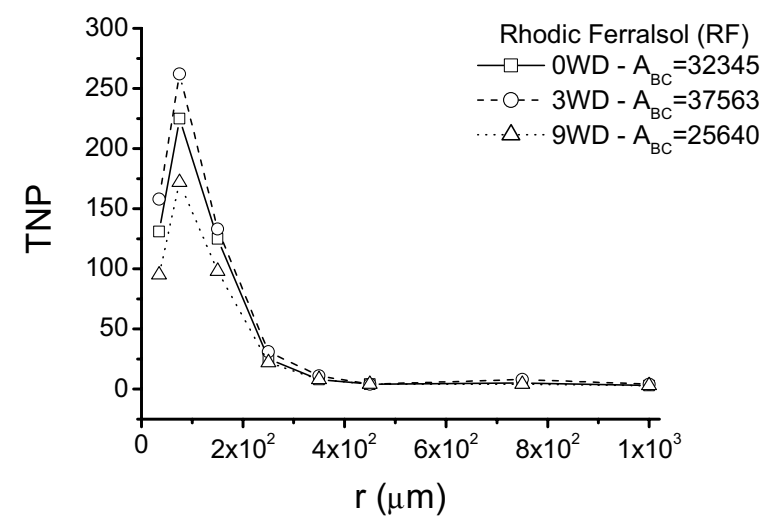

(C)

Fig. 3 - Changes in total number of pores (TNP) for different pore radii with repetitions of wetting and drying (W-D) cycles. $\mathrm{A}_{\mathrm{BC}}$ represents the calculated area below the curve $\left(\int_{r}(T N P) d r=A_{B C}\right)$. 
Geric Ferralsol (GF)

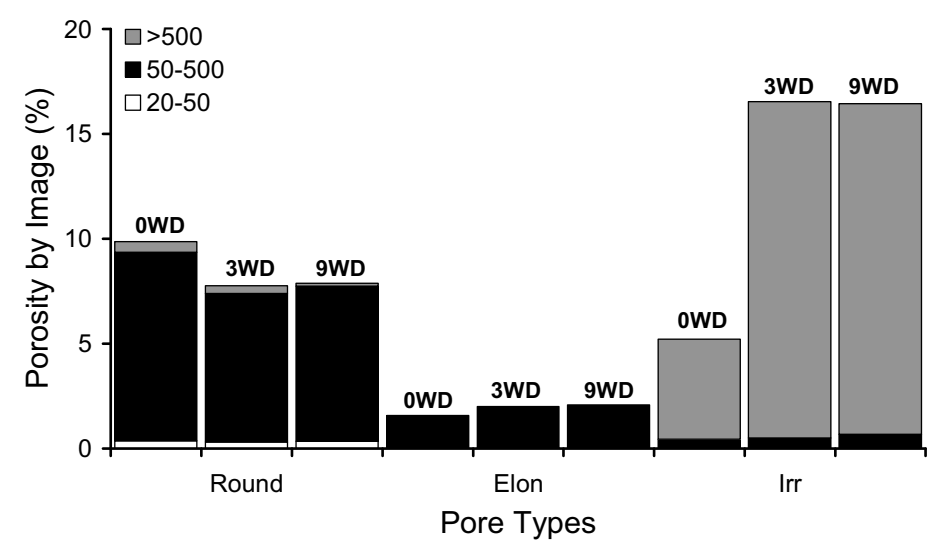

(A)

Eutric Nitosol (EN)

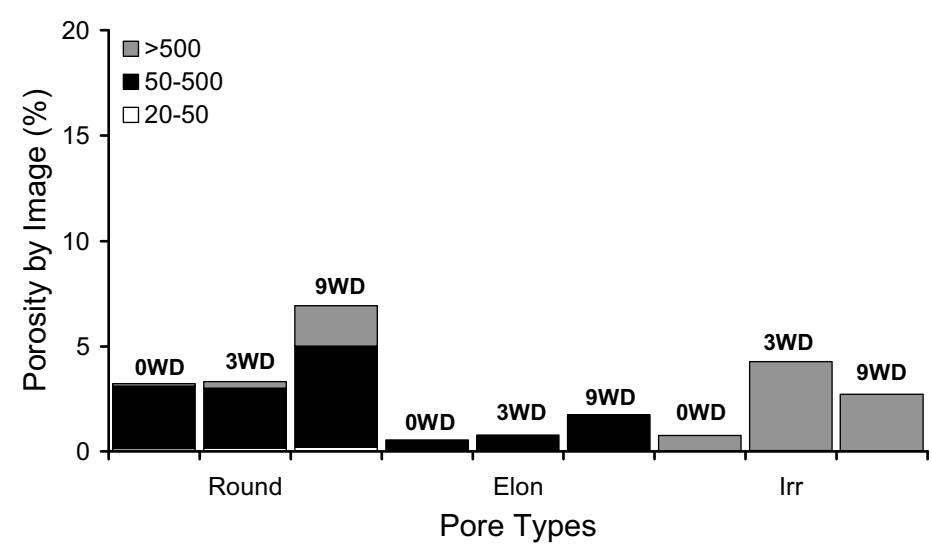

(B)

Rhodic Ferralsol (RF)

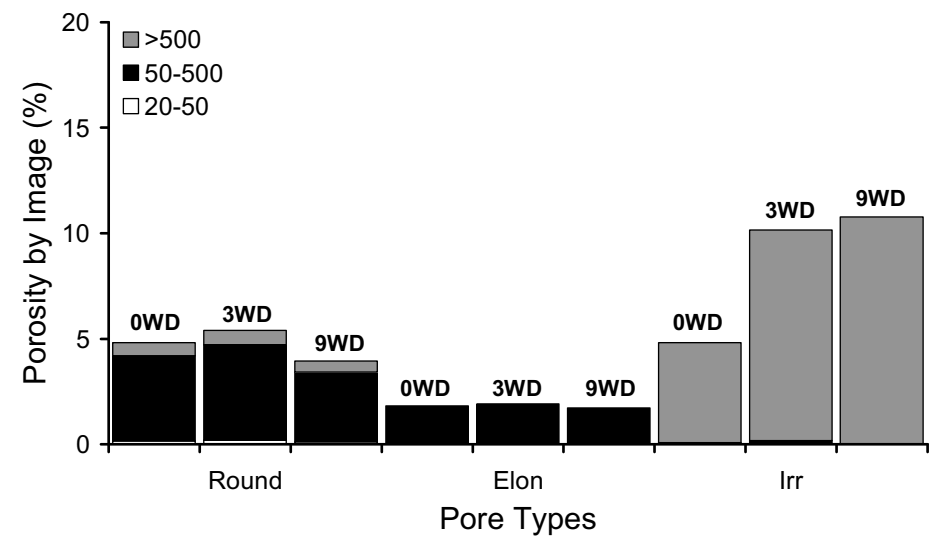

(C)

Fig. 4 - Effects of wetting and drying (W-D) cycles on the pore size distribution of damaged samples. Round = rounded; Elon = elongated; Irr = irregular; 0WD (samples not submitted to W-D cycles), 3WD (samples submitted to $3 \mathrm{~W}-\mathrm{D}$ cycles), and 9WD (samples submitted to $9 \mathrm{~W}-\mathrm{D}$ cycles) treatments. 
Contributions to $\phi$ due to rounded pores with radii between 20 and $1000 \mu \mathrm{m}$ decreased from 59\% (0WD) to $30 \%$ (9WD), and due to irregular ones passed from $31 \%$ (0WD) to 62\% (9WD). Several authors have shown modifications in SPS as a consequence of soil structure modifications resulting of natural soil processes or anthropogenic actions (Zund et al. 1997, Pillai and McGarry 1999, Bresson and Moran 2003, Kutílek et al. 2006).

For the EN soil (Fig. 4B), the percentage of $\phi$ related to rounded pores with radii varying from 20 to $500 \mu \mathrm{m}$ was reduced from $68 \%$ (0WD) to $44 \%$ (9WD), a different behavior as compared to the GF soil. The main contribution to $\phi$ for the 3WD treatment was due to the irregular pores larger than $500 \mu \mathrm{m}(51 \%)$. For $9 \mathrm{WD}, 17 \%$ of $\phi$ is related to rounded pores larger than $500 \mu \mathrm{m}$. Another important result for this soil was the increase factor of about 3.2 in the contribution of elongated transmission pores $(50-300 \mu \mathrm{m})$ to $\phi$ between 0WD and 9WD treatments. Changes in all classes and types of pores among treatments indicate some soil structure remediation with the sequences of W-D cycles.

The results for the RF soil (Fig. 4C) indicate that contributions of irregular pores larger than $500 \mu \mathrm{m}$ to $\phi$ varied from $41 \%$ (0WD) to $65 \%$ after $9 \mathrm{~W}-\mathrm{D}$ cycles. A slight decrease from 16 to $10 \%$ in the contribution of elongated transmission pores $(50-400 \mu \mathrm{m})$ to $\phi$ was observed. Also, after $9 \mathrm{~W}-\mathrm{D}$ cycles a decrease of rounded pores (from $42 \%$ to $24 \%$ ) was observed for RF soil samples. An increase in $\phi$ due to the raising of the number of pores larger than $500 \mu \mathrm{m}$ confirms that W-D cycle repetitions reduced the damaged areas for this type of soil.

Figure 5 illustrates the changes in pore morphology for all soils submitted to W-D cycles. The objective of showing these 2-D micromorphologic images is to give an insight on the effects of W-D cycles on damaged SPS.

In conclusion it can be said that there were remarkable differences between compacted SPS of OWD and those submitted to sequences of W-D cycles, for all soils. For all soil samples an evolution from massive structures (Figs. 5A, 5D and 5G) to structures with a great number of large and connected pores after W-D cycles could be noticed. A progressive increase in $\phi$ as the soil structure changed from massive, in plowed (disturbed) soils, to complex crumb, block, and platy after repeated W-D cycles was also reported by Hussein and Adey (1998). Pagliai et al. (1987) and Sartori et al. (1985), also demonstrating important modifications on the structure for different soil textures after sequences of W-D cycles. Viana et al. (2004) working with Brazilian Latosols showed similar results like those obtained by us for the GF soil and the RF soil after the application of $\mathrm{W}-\mathrm{D}$ cycles. The hydration and dehydration produces cycles of contraction and retraction of the clay particles and aggregates in a soil affecting its pore distributions. Aggregation by contraction promoted by gravitational forces produces large, irregularly distributed pores which in later stages of development are separated by connected pores as observed by Li et al. (2004).

During wetting and subsequent drying some soil physical properties may change by mechanical factors affecting the total porosity, stress state and energy state (Baumgartl 1998). The wetting and drying processes, in general, result in small alterations in total volume of the core sample (Pires et al. 2005), caused by stresses due to water/air interfaces originated from capillary forces, which increase with soil drainage. As a consequence, after each re-wetting process the soil structure will undergo modifications achieving a new state of energy, which most of the time promotes definitive changes in soil structure like the formation of connected soil pores (Viana et al. 2004).

To conclude it is important to recognize that the hydration of the soil samples used in this study was obtained through the capillary rise method, which sometimes can cause slaking of the soil aggregates leading to significant changes in soil structure. According to Baver et al. (1972) and Klute (1986) when a dry soil aggregate is suddenly surrounded by liquid water, capillary and adsorptive water forces drive the water into the aggregate, compressing the entrapped gas in the intraaggregate pores. In this case an aggregate instability will take place due to an internal collapse caused by the escape of compressed air trapped in the micropores. The procedure of dehydration by using $400 \mathrm{kPa}$ of pressure also can induced some changes in soil structure due to pressure and temperature effects during the time needed to obtain the thermodynamic equilibrium (Moraes et al. 1993). 


\section{Geric Ferralsol (GF)}

OWD

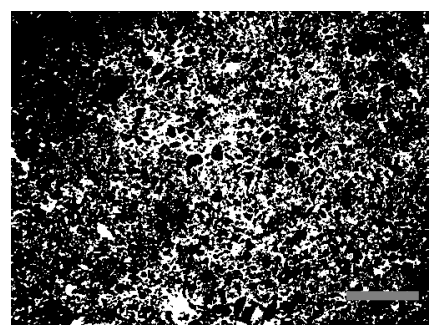

(A)

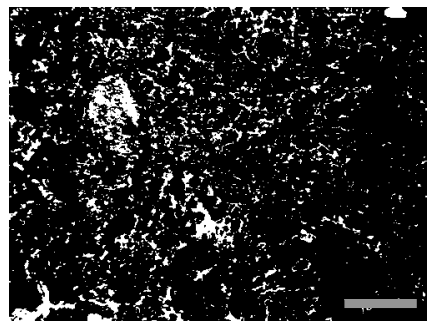

(D)

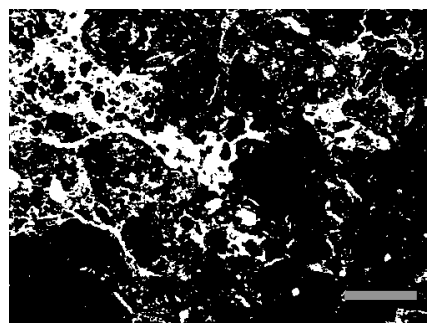

(G)
3WD

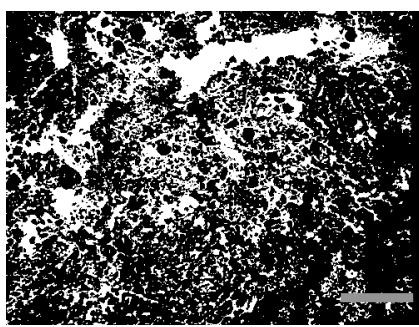

(B)

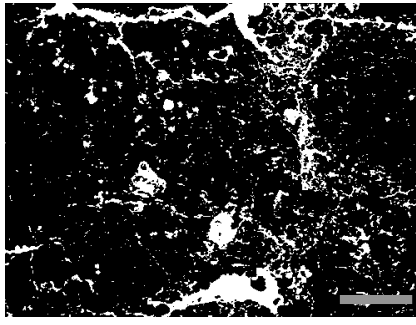

(E)

Rhodic Ferralsol (RF)

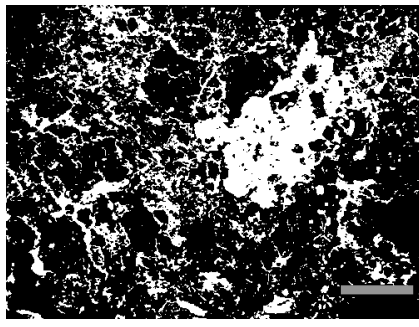

(H)

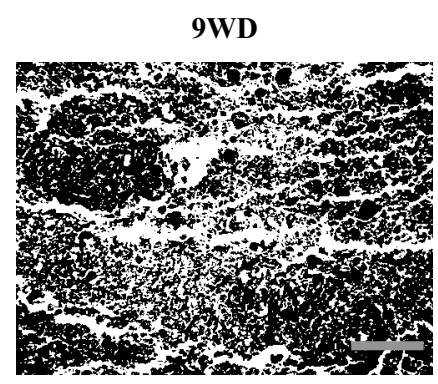

(C)

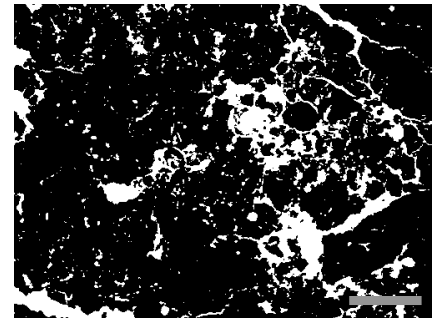

(F)

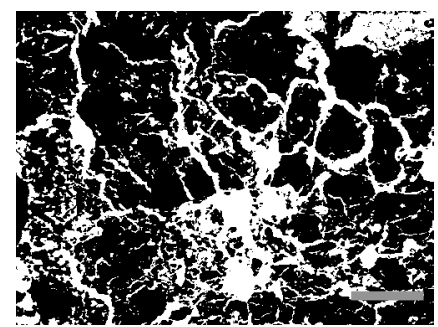

(I)

Fig. 5 - Binary images (pores appear in white and the soil matrix in black) representing the variations on the soil pore system (SPS) of damaged samples with repetitions of wetting and drying (W-D) cycles. Lines at the right corner of the images represent the scale (1000 $\mu \mathrm{m})$.

\section{ACKNOWLEDGMENTS}

To Fundação Araucária (Grants no. 10193 and 10195), Fundo Paraná/SETI, Estado do Governo do Paraná and to Conselho Nacional de Desenvolvimento Científico e Tecnológico (CNPq) for financial support.

\section{RESUMO}

A caracterização da estrutura do solo usando a análise de imagens bidimensionais (2-D) constitui um método simples na obtenção de informações essenciais relacionadas com a porosidade do solo e a distribuição do tamanho de poros. Tal infor- mação é importante para obter dados sobre a qualidade do solo, a qual está diretamente ligada à sua estrutura e aos processos de transporte que ocorrem no seu interior. Na maior parte do tempo os solos são submetidos a vários ciclos de umedecimento ("wetting") e secamento ("drying") (W-D) que podem causar importantes mudanças em solos que possuem estruturas danificadas. Neste estudo foi usada a análise de imagens em 2-D na avaliação de possíveis modificações devido a vários ciclos de W-D na estrutura de amostras de solo danificadas. Três solos diferentes em textura (Latossolo vermelho-amarelo distrófico - LVAd; Nitossolo vermelho eutrófico - NVe, Latossolo vermelho distrófico - LVd) foram submetidos a três dife- 
rentes tratamentos: 0WD, amostras controle não submetidas a nenhum ciclo de W-D; $3 \mathrm{WD}$ e 9WD, amostras submetidas a $3 \mathrm{e}$ 9 ciclos consecutivos de W-D, respectivamente. Foi observado que os ciclos de W-D produziram mudanças significativas nos poros grandes irregulares dos solos LVAd e LVd e nos poros arredondados do NVe. Importantes mudanças nos poros de 35 até $150 \mu \mathrm{m}$ foram observadas para todos os solos estudados. A partir dos resultados obtidos pode ser dito que o uso da análise de imagens auxiliou com sucesso na explicação de variações no sistema poroso (formato, número e distribuição de tamanho dos poros) devido aos ciclos de W-D para todos os solos analisados.

Palavras-chave: densidade do solo, umidade do solo, porosidade do solo, micromorfologia, estrutura do solo, compactação.

\section{REFERENCES}

ATtOU F AND BRUAND A. 1998. Experimental study of "fragipans" formation in soils. Role of both clay dispersion and wetting-drying cycles. Earth Plan Sci 326: 545552.

Augeard B, Bresson LM, Assouline S, Kao C And VAUCLIN M. 2008. Dynamics of soil surface bulk density: role of water table elevation and rainfall duration. Soil Sci Soc Am J 72: 412-423.

BaUmgartl TH. 1998. Physical soil properties in specific fields of application especially in anthropogenic soils. Soil Till Res 47: 51-59.

BAVER LD, GARdner WH AND GARdNER WR. 1972. Física de Suelos. México: UTHA.

Bouma J, Jongerius A AND SCHOONDERBEeK D. 1979. Calculation of saturated hydraulic conductivity of some pedal clay soils using micromorphometric data. Soil Sci Soc Am J 43: 261-264.

BRESSON LM AND MorAN CJ. 1995. Structural changes induced by wetting and drying in seedbeds of a hardsetting soil with contrasting aggregate size distribution. Eur J Soil Sci 46: 205-214.

BRESSON LM AND MORAN CJ. 2003. Role of compaction versus aggregate disruption on slumping and shrinking of repacked hardsetting seedbeds. Soil Sci 168: 585-594.

BRESSON LM AND MORAN CJ. 2004. Micromorphological study of slumping in a hardsetting seedbed under various wetting conditions. Geoderma 118: 277-288.

Bullock P And Thomasson AJ. 1979. Rothamsted studies of soil structure. II. Measurement and characterization of macroporosity by image analysis and comparison with data from water retention measurements. J Soil Sci 30: 391-413.

ChertKov VY AND RaVina I. 2000. Shrinking-swelling phenomenon of clay soils attributed to capillary-crack network. Theor Appl Fract Mech 34: 61-71.

CoOper M, Vidal-Torrado P AND Chaplot V. 2005. Origin of microagregates in soils with Ferric horizons. Sci Agr 62: 256-263.

HorGAN GW. 1998. Mathematical morphology for analyzing soil structure from images. Eur J Soil Sci 49: 161-173.

HUSSEIN J AND ADEY MA. 1998. Changes in microstructure, voids and b-fabric of surface samples of a Vertisol caused by wet/dry cycles. Geoderma 85: 63-82.

Jongerius A, SchoonderbeEK D AND JAGER A. 1972. The application of the Quantimet 720 in soil micromorphometry. The Microscope 20: 243-254.

KLUte A. 1986. Water retention: laboratory methods. In: BLACK CA (Ed), Methods of soil analysis. I. Physical and mineralogical methods. Soil Science Society America Book Series: Madison, 635-662.

Kutílek M, Jendele L and Panayiotopoulos KP. 2006. The influence of uniaxal compression upon pore size distribution in bi-modal soils. Soil Till Res 86: 27-37.

Li D, Velde B AND Zhang T. 2004. Observations of pores and aggregates during aggregation in some clayrich agricultural soils as seen in 2D image analysis. Geoderma 118: 191-207.

Lima HV, Silva AP, SAntos MC, CoOper M AND ROMERO RE. 2006. Micromorphology and image analysis of a hardsetting Ultisol (Argissolo) in the state of Ceará (Brazil). Geoderma 132: 416-426.

Moraes SO, Libardi PL And Dourado Neto D. 1993. Problemas metodológicos na obtenção da curva de retenção da água pelo solo. Sci Agr 50: 383-392.

MURPHY CP. 1986. Thin section preparation of soils and sediments. Berkhamsted: Academic Publishers.

Murphy CP, Bullock P AND Turner RH. 1977a. The measurement and characterization of voids in soil thin sections by image analysis: Part I. Principles and techniques. J Soil Sci 28: 498-508.

Murphy CP, Bullock P AND Biswell KJ. 1977b. The measurement and characterization of voids in soil thin sections by image analysis: Part II. Aplications. J Soil Sci 28: 509-518.

Newman ACD And Thomasson AJ. 1979. Rothamsted studies of soil structure: III. Pore size distributions and shrinkage processes. J Soil Sci 30: 415-439. 
Oliveira TS, Costa LM AND Schaefer CE. 2005. Water-dispersible clay after wetting and drying cycles in four Brazilian oxisols. Soil Till Res 83: 260-269.

PAGLIAI M. 1987. Micromorphometric and micromorphological investigations on the effect of compaction by pressures and deformations resulting from tillage and wheel traffic. In: MonNiER G AND Goss MJ (Eds), Soil compaction and regeneration. AA Balkema, Rotterdam, p. 31-38.

Pagliai M, La Marca M and Lucamante G. 1987. Changes in soil porosity in remolded soils treated with poultry manure. Soil Sci 144: 128-140.

Pardini G, Vigna Guidi G, Pini R, Regués D AND GALlART F. 1996. Structure and porosity of smectitic mudrocks as affected by experimental wetting-drying cycles and freezing-thawing cycles. Catena 27: 149-165.

PILlAi-MCGARRY UPP. 1991. Regeneration of soil structure. Aust Cottongrower 11: 51-52.

Pillai-McGarry UPP AND Collis-George N. 1990. Laboratory simulation of the surface morphology selfmuching and non self-mulching Vertisols. I. Materials, methods and preliminary results. Aust J Soil Res 28: 129-139.

Pillai UP AND MCGarRy D. 1999. Structure repair of a compacted Vertisol with wet-dry cycles and crops. Soil Sci Soc Am J 63: 201-210.

Pires LF, BACChi OOS AND ReICHARDT K. 2004. Damage to soil physical properties caused by soil sampler devices as assessed by gamma ray computed tomography. Austr J Soil Res 42: 857-863.

PIRES LF, BACCHI OOS AND REICHARDT K. 2005. Gamma ray computed tomography to evaluate wetting/drying soil structure changes. Nucl Instr Meth Phys Res B 42: 857-863.
RAJARAM G AND ERBACH DC. 1999. Effect of wetting and drying on soil physical properties. J Terramechanics 36 : $39-49$.

RINGROSE-VOASE AJ. 1990. One-dimensional image analysis of soil structure. I. Principles. J Soil Sci 41: 499-512.

Sarmah AK, Pillai-McGarry U AND MCGARry D. 1996. Repair of the structure of a compacted Vertisol via wet/dry cycles. Soil Till Res 38: 17-33.

SARTORi G, Ferrari GA AND PAgliai M. 1985. Changes in soil porosity and surface shrinkage in a remolded, saline clay soil treated with compost. Soil Sci 139: 523-530.

SAS Institute. 1996. System for Information. Version 6.11. Cary, SAS Institute Inc., 1996.

Telfair D, Gardner MR And Miars D. 1957. The restoration of a structurally degenerated soil. Soil Sci Soc Am J 21: 131-134.

ThOMpson ML, Singh P, CORAK S AND STRAszheim WE. 1992. Cautionary notes for the automated analysis of soil pore-space images. Geoderma 53: 399-415.

Viana JHM, Fernandes Filho EI AND Schaefer CEGR. 2004. Efeitos de ciclos de umedecimento e secagem na reorganização da estrutura microgranular de latossolos. R Bras Ci Solo 28: 11-19.

Wakindiki IIC AND Ben-HuR M. 2002. Soil Mineralogy and texture effects on crust micromorphology, infiltration, and erosion. Soil Sci Soc Am J 66: 897-905.

ZUND PR, PILlai-McGarry U, MCGARRY D AND BRAY SG. 1997. Repair of a compacted Oxisol by the earthworm pontoscolex corethrurus (Glossoscolecidae, Oligochaeta). Biol Fertl Soils 25: 202-208. 